\title{
Terrestrial arthropods of Bouvetøya
}

\author{
LAURITZ SØMME
}

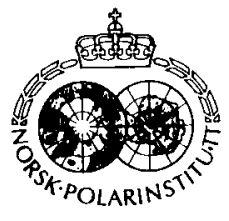

Sømme, L. 1986: Terrestrial arthropods of Bouvetøya. Polar Research 4 n.s., 231-233.

Steveacarus evansi (Hunter) (Acari, Mesostigmata) and Friesea tilbrooki Wise (Collembola) are reported for the first time from Bouvetøya $\left(54^{\circ} 25^{\prime} \mathrm{S}, 3^{\circ} 21^{\prime} \mathrm{E}\right)$. At present a total of four free-living species of Acari and three species of Collembola are known from this isolated island.

Lauritz Sømme, Department of Biology, Division of Zoology, University of Oslo, P.O. Box 1050, Blindern, N-0316 Oslo 3, Norway; (accepted September 1986).

Bouvetøya is situated at $54^{\circ} 25^{\prime} \mathrm{S}$ and $3^{\circ} 21^{\prime} \mathrm{E}$ in the South Atlantic Ocean (Orheim 1981). Due to its isolated position this uninhabited island is rarely visited, and relatively few biological studies have been performed. The island lies within the Maritime Antarctic zone (Holdgate 1964). The vegetation consists of algae, lichens, fungi and bryophytes (Engelskjøn 1981). No vascular plants have been found.

Records of free-living terrestrial arthropods at Bouvetøya have previously been published by Tilbrook (1967) and Holdgate et al. (1968). A total of two species of Collembola and four species of Acari were reported. During the Norwegian Antarctic Research Expedition 1978/79 several samples of terrestrial arthropods were collected from different sites on the island. The availability of a helicopter made it possible to collect samples at higher elevations. In addition to the species that have previously been reported, two new species were found. The present paper gives a complete list of all free-living terrestrial arthropods so far known at Bouvetøya. Geographical names are according to the map of Bouvetøya (Norsk Polarinstitutt 1986, 1:20,000).

\section{Localities}

1. Nyrøysa 27 Dec. 1978. - About $40 \mathrm{~m}$ a.s.l., under rocks between vegetation of lichens, mosses and Prasiola-algae, close to nests of cape pigeons and southern fulmars. Arthropods were collected by hand.
2. Nyrøysa 31 Dec. 1978. - At the border of the rookery of chinstrap and macaroni penguins and around resting places for fur seals. Handcollected under rocks between Prasiola and moss (Brachytecium sp.).

3. Mountain ridge above Nyrøysa, about 150 ma.s.l., 29 Dec. 1978. - The ridge is covered by fields of mosses (Turtula sp., Brachytecium sp.). Arthropods were hand-collected from rocks between Prasiola and lichens (Usnea sp.) close to nests of cape pigeons and southern fulmars. More specimens were obtained from samples of algae, mosses and lichens extracted in Tullgren funnels.

4. Moseryggen 1 Jan. 1979 at 287 ma.s.l. - The small cliff is surrounded by glaciers and has a rich vegetation of mosses (Andreaea sp., Polytrichum sp.) and lichens (e.g. Usnea sp., Stereocaulon sp.). Samples of mosses and lichens were extracted in Tullgren funnels.

5. Kapp Valdivia 30 Dec. 1978 at about 100 m a.s.l. - From rocky grounds with sparse vegetation of moss (Drepanocladus sp.). Arthropods were hand-collected close to nests of cape pigeons and southern fulmars and extracted from samples of moss.

\section{Acari}

Nanorchestes antarcticus Strandtmann

This prostigmatid mite is widely distributed in 
the Antarctic (Strandtmann 1967), including the Maritime islands and South Georgia. It has previously been recorded at Bouvet $\emptyset$ ya by Holdgate et al. (1968) and was collected at loc. 1 during the present study.

\section{Protereunetes minutus Strandtmann}

This species, which also belongs to the Prostigmata, is known from the Antarctic Peninsula, the Maritime islands and South Georgia (Strandtmann 1967). It was not found during the present study, but has been reported from Bouvetøya by Holdgate et al. (1968).

\section{Alaskozetes antarcticus (Mich.) ssp. intermedius Wallwork}

According to Wallwork (1973) the nominate form occurs on the Antarctic Peninsula, the South Shetland and South Orkney Islands, while $A$. antarcticus ssp. intermedius is reported from the South Sandwich Islands and South Georgia. The last form was also recorded at Bouvetøya by Holdgate et al. (1968). It appears to be widespread and numerous on the island and was found in all samples during the present study. Alaskozetes bouvetøyaensis, reported from Bouvetøya by van Pletzen \& Kok (1971), is presumably synonymous to the intermedius form.

\section{Steveacarus evansi (Hunter)}

The species belongs to the Mesostigmata and has previously only been reported from Macquarie Island and South Georgia (Hunter 1970). At Bouvetøya it appeared to be widespread and was found at all locations during the present study.

\section{Collembola}

\section{Cryptopygus antarcticus Willem}

C. antarcticus is probably the most common species of Collembola in the Antarctic and is widely distributed within the Maritime and subAntarctic zones (Wise 1967; Wallwork 1973). It was reported at Bouvetøya by Holdgate et al. (1968), who found that the specimens ranged in size from 320 to $1,250 \mu \mathrm{m}$. They are smaller than specimens of $C$. antarcticus from the South Orkney Islands, which obtain a length of up to $2,000 \mu \mathrm{m}$ (Tilbrook 1967). During the present study $C$. antarcitcus was found on all locations, usually in vast numbers. In a sample of 8,000 individuals the size ranged from 250 to $1,300 \mu \mathrm{m}$.

\section{Archisotoma brucei (Carpenter)}

This species is widely distributed in the Maritime Antarctic zone (Wise 1967; Wallwork 1973) and has been recorded at Bouvetøya by Holdgate et al. (1968). During the present study about 15 specimens were collected under rocks at Kapp Valdivia (loc. 5).

\section{Friesea tilbrooki Wise}

The only previous record of this species is from South Georgia (Wise 1970). At Bouvetøya about 20 specimens were collected at Nyrøysa in vegetation at the border of the penguin rookery (loc. 2).

\section{Discussion}

At present three species of Collembola and four species of Acari are known from Bouvetøya. The poverty of the fauna of free-living terrestrial arthropods reflects the isolated position of the island. Bouvetøya is of volcanic origin, emerging above sea level between one and two million years ago (Prestvik \& Winsnes 1981). Accordingly, the present fauna is not a relic of an older and richer continental fauna, as suggested for some Antarctic micro-arthropods (Wallwork 1973). How the present species of Bouvetøya arrived is uncertain. As discussed by Wallwork (1973) the relic Antarctic fauna has probably been joined by a penetrant element. There is evidence to suggest that dispersal of micro-arthropods may take place over wide stretches of ocean.

All species of Bouvetøya are found further to the south or south-west in the Maritime or subAntarctic zones. Frisea tilbrooki is known only from South Georgia (Wise 1970), and Alaskozetes antarcticus ssp. intermedius only from South Georgia and the South Sandwich Islands (Wallwork 1973). Stereacarus evansi is also known from South Georgia (Hunter 1970), and Protereunetes minutus has a western distribution in the Maritime zone (Strandtmann 1967). The remaining species of Acari and Collembola are more widespread in the Maritime and Sub-Antarctic zones (Wallwork 1973). The patterns of distribution of the micro- 
arthropods parallel the distribution of the bryophytes and lichens of Bouvetøya, which are widespread in the Maritime Antarctic to the southwest (Engelskjøn 1981; Engelskjøn \& Jørgensen 1986).

The prevailing winds at Bouvetøya are also from the southwest, and wind-dispersal is one way of explaining the arrival of micro-arthropods on the island. More likely, they have arrived with birds, which would offer better protection during transport. In addition, the birds are likely to land on snow- and ice-free habitats, where living conditions for micro-arthropods may be found in the vegetation.

Acknowledgements. - Matcrial for the present study was collected under the logistic support of NARE 1978/79. I want to thank Dr. T. Engelskjøn, University of Oslo, for identification of plant material in the field. I am also most grateful to the following persons for the identification of terrestrial arthropods: Professor P. Hunter, University of Georgia (Steveacarus evansi), Professor J. A. Wallwork, University of London (Alaskozetes antarcticus ssp. intermedius), P. N. Lawrence, British Museum (Natural History) (Cryptopygus antarcticus) and Dr. K. A. J. Wise, Auckland Institute and Museum (Friesea tilbrooki).

\section{References}

Engelskjøn, T. 1981: Terrestrial vegetation of Bouvet $\varnothing y a$. A preliminary account. Norsk Polarinst. Skr. 175, 17-28.
Engelskjøn, T. \& Jørgensen, P. M. 1986: Phytogeographical relations of the Bouvetøya cryptogamic fiora. Norsk Polarinst. Skr. 185, 71-79.

Holdgate, M. W. 1964: Terrestrial ecology in the Maritime Antarctic. Pp. 181-194 in Carrick, R., Holdgate, M. W. \& Prévost, J. (eds.): Biologie Antarctique. Hermann, Paris.

Holdgate, M. W., Tilbrook, P. J. \& Vaughan, R. W. 1968: The biology of Bouvetøya. Br. Antarct. Surv. Bull. 15, 1-7.

Hunter, P. E. 1970: Acarina, Mesostigmata: Free-living mites of South Georgia and Heard Island. Pacif. Insects Monogr. $23,43-70$.

Orheim, O. 1981: Foreword. Bouvetøya, South Atlantic Ocean. Norsk Polarinst. Skr. 175, 5.

van Pletzen, R. \& Kok, D. J. 1971: Oribatei. Pp. 314-326 in van Zinderen Bakker, E. M., Winterbottom, J. M. \& Dyer, R. A. (eds): Marion and Prince Edward Island: Report on the South African biological and geological expeditions 19651966. A. A. Balkema, Cape Town.

Prestvik, T. \& Winsnes, T. S. 1981: Geology of Bouvetøya, South Atlantic, Norsk Polarinst. Skr. 175, 41-69.

Strandtmann, R. W. 1967: Terrestrial Prostigmata (Trombidiform mites). Pp. 51-80 in Gressit, J. L. (ed.): Entomology of Antarctica. Antarctic Res. Ser. 10. American Geophysical Union, Washington, D.C.

Tilbrook, P. J. 1967: The terrestrial invertebrate fauna of the Maritime Antarctic. Phil. Trans. R. Soc. Lond. B252, 261278.

Wallwork, J. A. 1973: Zoogeography of some terrestrial microarthropoda in Antarctica. Biol. Rev. 48, 223-259.

Wise, K. A. J. 1967: Collembola (springtails). Pp. 123-148 in Gressit, J. L. (ed.): Entomology of Antarctica. Antarctic Res. Ser. 10. American Geophysical Union, Washington, D.C.

Wise, K. A. J. 1970: Collembola of South Georgia. Pacif. Insects. Monogr. 23, 183-203. 